\title{
Conditional mutualism between the giant kelp Macrocystis pyrifera and colonial epifauna
}

\author{
Christopher D. Hepburn*, Catriona L. Hurd \\ Department of Botany, University of Otago, PO Box 56, Dunedin, New Zealand
}

\begin{abstract}
It is generally considered that colonial invertebrates living on the surfaces of macroalgae have a negative influence on the growth rates and survivorship of their substratum. To date no evidence has been provided from natural macroalgal/epifaunal associations to support this view. We investigated the influence of colonial bryozoans and hydrozoans on the growth rate and nitrogen physiology of their substratum, the giant kelp Macrocystis pyrifera, and the impact of seasonal changes of light and the seawater nitrogen concentration on this relationship. Throughout this study there was no evidence of any negative impact of colonization by either epifaunal group on the growth of M. pyrifera. During a period of low concentrations of inorganic nitrogen in seawater, the growth of M. pyrifera fronds heavily colonized by hydroid colonies was higher than less heavily colonized individuals. During this time hydroids could provide on average between 71 and $122 \%$ of the nitrogen required for uptake by tagged $M$. pyrifera fronds at ambient seawater nitrogen concentrations. Evidence suggests that enhanced growth was caused by the provision of ammonium excreted by the hydroid colonies. Evolutionary pressure to limit the impact of colonization by sessile animals on macroalgae is likely to be exerted on both the algal substratum and the attached animal. We suggest that due to their close relationship this pressure may ultimately result in the development of mutualistic partnerships between algae and specialized sessile seaweed-dwelling fauna in natural associations.
\end{abstract}

KEY WORDS: Mutualism $\cdot$ Kelp $\cdot$ Hydroids $\cdot$ Bryozoans $\cdot$ Epifauna $\cdot$ Nitrogen limitation $\cdot$ Ammonium excretion $\cdot$ Sessile invertebrates

\section{INTRODUCTION}

The surfaces of subtidal macroalgae are often heavily colonized by colonial suspension-feeding animals that are specialized for life on macroalgae and are rarely found on the benthos. Some of the most common colonial inhabitants of macroalgal surfaces include bryozoans and hydrozoans (e.g. Hagermann 1966, Norton 1971, Ryland 1974, Bernstein \& Jung 1979, Yoshioka 1982, Oswald \& Seed 1986, Orlov 1996, Fraschetti et al. 2002). After settlement of their larvae, sessile colonial epifauna become completely reliant on their algal substratum for their survival; it can be predicted that these animals will have developed mechanisms to reduce harm to their substratum. Studies to date, however, suggest these animals can have a marked, primarily negative, influence on colonized sections of algal tissue. Colonial epifauna can shade algal tissue (Oswald et al. 1984, Cancino et al. 1987, Muñoz et al. 1991), provide a barrier to nutrient uptake (Hurd et al. 1994, 2000), inhibit sporulation (Kain 1975), increase susceptibility to wave and current damage (Dixon et al. 1981, Lambert et al. 1992, Schiebling et al. 1999, Hepburn 2003), and cause damage as a result of fish feeding on attached colonies (Bernstein \& Jung 1979, Yoshioka 1982, Hepburn 2003). This information has led to the concept that colonization by sessile epifauna has a negative effect on growth and survivorship of algae when heavily colonized by sessile epifauna (Lobban 1978a, Dieckmann 1980, Dean \& Jacobsen 1984). In situations where sessile epifauna have been accidentally released beyond 
their natural range, they have caused extensive defoliation of macroalgal beds (Lambert et al. 1992, Scheibling et al. 1999). Despite their strong impact on algal tissue directly beneath colonies there is no evidence to suggest that in natural associations sessile epifauna have any overall effect on the growth, survivorship, or fecundity of colonized algae. Indeed, the only study to date that has directly investigated the impact of sessile epifauna (a bryozoan) on algal growth found no evidence of lower growth rates in colonized algae compared to algae free from colonization (Cancino et al. 1987).

There is a strong basis for the development of mutualistic relationships between sessile epifauna and the algae they inhabit. Sessile epifauna and their algal substrata are in direct physical contact and the larvae of epifauna often select specific algal species or functional groups for settlement (Bernstein \& Jung 1979, Seed \& O'Connor 1981, Oswald \& Seed 1986), and both partners in this relationship can provide advantages to each other. Algae provide a refuge from the competitive benthos for diminutive epifauna (Oswald \& Seed 1986). Larger algae may also provide a means of projection of attached suspension-feeding animals above the low flow rates and high levels of sedimentation that occur in the benthic boundary layer into a more favorable feeding environment (Duggins et al. 1990, Eckman \& Duggins 1991). Algae also provide a supplement to food filtered from the water column by epifauna in the form of kelp-derived dissolved and particulate organic matter (De Burgh \& Fankboner 1978, Oswald \& Seed 1986, Manriquez \& Cancino 1996). Epifauna may provide ammonium (Gerard \& Mann 1979, Probyn \& Chapman 1983, Hurd et al. 1994, Taylor \& Rees 1998) and carbon dioxide (Mercado et al. 1998) to colonized macroalgae, providing advantages during periods when these nutrients might limit algal growth.

The kelp Macrocystis pyrifera L. C. Agardh has a wide geographic distribution and forms the base of the highly productive and ecologically important kelp forest ecosystem (reviewed in Dayton 1985, Foster \& Schiel 1985, Steneck et al. 2002). Throughout its range, the extensive thallus of $M$. pyrifera is colonized by sessile epifauna (Barrales \& Lobban 1975, Bernstein \& Jung 1979, Yoshioka 1982). The primary objective of the present study was to detect any affects of colonization by dominant groups of sessile epifauna (hydrozoans and bryozoans) on $M$. pyrifera growth rates and nitrogen status and how seasonal changes in light and seawater nitrogen influence this relationship. We hypothesized that high levels of colonization by epifauna would enhance the growth rate of $M$. pyrifera via ammonium provision only during periods when growth was limited by low nitrogen. Ammonium ex- cretion was predicted to be of little value to the seaweed substratum during the winter, as seawater nitrogen concentrations are likely to be high and shading of colonized tissue by epifauna could exacerbate the effects of low irradiance levels. A nitrogen budget was developed for colonized $M$. pyrifera fronds using ammonium excretion rates of hydroid and bryozoan colonies and nitrogen uptake rates by $M$. pyrifera. This information was developed to determine if epifauna made a significant contribution to total nitrogen uptake during periods when $M$. pyrifera growth was nitrogen limited.

\section{MATERIALS AND METHODS}

Study site. The study site, Harington Point $\left(45^{\circ}\right.$ $47^{\prime} 03.5^{\prime \prime} \mathrm{S}, 170^{\circ} 43^{\prime} 22.7^{\prime \prime} \mathrm{E}$ ), forms a bottleneck at the entrance to Otago Harbor (South Island, New Zealand) and as a result is subjected to strong tidal flow (up to $0.45 \mathrm{~m} \mathrm{~s}^{-1}$ ). Blades of the dense stand of Macrocystis pyrifera found at Harington Point are often heavily colonized by colonial suspension-feeding animals. This community is dominated by the bryozoan Membranipora membranacea L. \& Ryther, and the hydrozoan Obelia geniculata L. Smaller $(<2 \mathrm{~cm})$ colonies of the bryozoan Celleporella bathamae Gordon were also found.

Environmental parameters. Monthly averages of 'global' radiation ( $\mathrm{MJ} \mathrm{m} \mathrm{m}^{-2} \mathrm{~d}^{-1}$ ) were obtained from a weather station in Dunedin, approximately $20 \mathrm{~km}$ south-west of Harington Point (data courtesy of the National Institute of Water and Atmospheric Research).

Seawater samples for nitrate and ammonium concentrations were collected at low tide from the water's surface and near the substratum $(4 \mathrm{~m})$ by divers from within the Harington Point kelp bed from August 1998 to April 2000. Samples were filtered (Whatman GF/C filters), and nitrate and ammonium concentrations were determined using a Lachat Quickchem 8000 automated ion analyzer.

Determination of frond growth, nitrogen status and levels of epifaunal colonization. A total of 20 mature Macrocystis pyrifera individuals were haphazardly selected, and from each one an actively growing frond (with an apical meristem) was tagged using labeled surveyor's flagging tape at low tide on 10 separate occasions between April 1998 and August 1999, and twice during January and February 2000. For each tagged frond, growth parameters, bryozoan and hydroid colonization levels, blade surface area and nitrogen status were determined.

The top sections of the fronds were pulled on board a small boat, and tags were loosely tied on (so as not to restrict stipe growth) immediately behind the apical 
meristem and around the base of 3 consecutive healthy blades, the first being 5 blades down the frond from the frond apex (Fig. 1). Blade growth was measured using a modification of the punched-hole method (Parke 1948). A small circular hole $(0.5 \mathrm{~cm}$ diameter $)$ was cut $10 \mathrm{~cm}$ back from the tip of each tagged blade, and the distance between the pneumatocyst-blade junction and the inside of the punched hole was then measured to the nearest millimeter $\left(B_{1}\right.$ to $\left.B_{3}\right)$. Internode length was measured at 3 points along each stipe; between the connection of the stipe to the pneumatocyst of each tagged blade to the next pneumatocyst-stipe connection up the frond ( $\mathrm{I}_{1}$ to $\left.\mathrm{I}_{3}\right)$. To determine the production of new blades at frond apices a tag $\left(\mathrm{T}_{1}\right)$ was tied loosely behind the apical meristem.

After approximately $2 \mathrm{wk}$ (dependent on weather), the entire tagged fronds were cut at their bases by divers, carefully untangled and returned to the laboratory (approximately $1 \mathrm{~h}$ away). New blades produced in front tag $T_{1}$ directly behind the apical scimitar and total number of blades per frond were counted. Tagged blades and stipe sections were re-measured and relative growth rates (RGR) of the blades and internodes per day were determined from:

$$
\operatorname{RGR}=\frac{\ln \left(D_{2} D_{1}\right)}{T}
$$

where $D_{1}$ is the initial distance between the punched hole and blade/pnuematocyst junction (blade growth) or between nodes (internode growth), $D_{2}$ is the distance between the same points after the tagging period, and $T$ is the number of days between tagging and collection (Brown et al. 1997).

After the number of blades per tagged frond was determined, each frond was divided into thirds, termed the top, middle and base. From each frond third, 5 blades were selected in a regular fashion (e.g. if there were 10 blades in each frond third every second blade was selected, every third blade for 15 blades, etc.) giving a total of 15 blades for each tagged frond. A Perspex sheet with a $2 \times 2 \mathrm{~cm}$ grid was used to determine blade surface area and the percentage cover of bryozoan and hydroids on both sides of the 15 selected blades. From these counts, blade surface area and percentage bryozoan and hydroid cover of blades from the top, middle and base of fronds was estimated. Percentage cover of bryozoans and hydroids was determined because they were by far the most common inhabitants of Macrocystis pyrifera tissue at the study site and appeared to have the potential to cause the greatest impact on their seaweed substratum. No separation to species level of bryozoans or hydroids was made while determining colonization levels.

Nitrogen status was determined for blades selected from the top, middle and base for all tagged fronds.

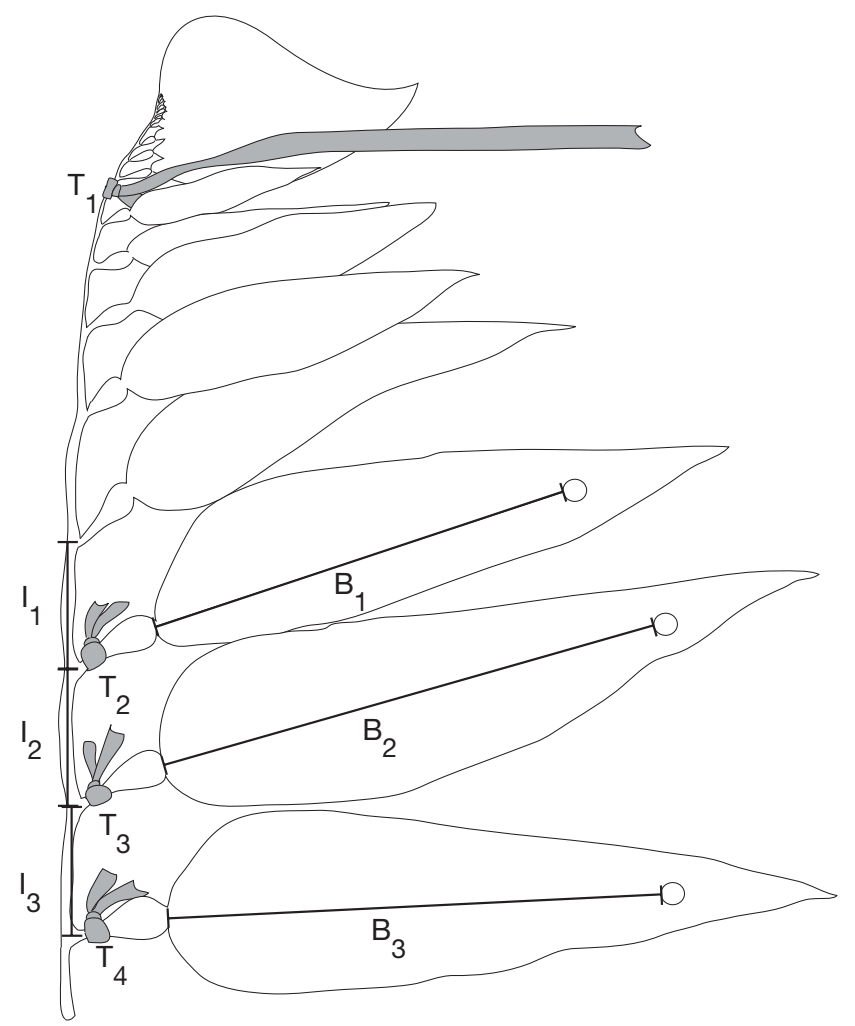

Fig. 1. Macrocystis pyrifera. Position of tags and growth measurements on each frond. Tagging points: $T_{1}, T_{2}, T_{3}, T_{4}$ blade growth measurements: $\mathrm{B}_{1}, \mathrm{~B}_{2}, \mathrm{~B}_{3}$; internode growth measurements: $I_{1}, I_{2}, I_{3}$

This sampling plan was designed to allow detection of nitrogen enrichment coinciding with high epifaunal loads localized on certain parts of the frond and to allow a more accurate assessment of the overall nitrogen status of tagged fronds. From the middle blade of each frond third, two $1.8 \mathrm{~cm}$ diameter discs were cut from tissue free of epifauna using a leaf corer. The first blade tissue disc was assayed for soluble tissue nitrate and ammonium concentrations using a boiling water extraction (Hurd et al. 1996), expressed on a dry weight basis. Dry weight was determined using wet to dry weight ratios obtained from the second tissue disc taken from adjacent tissue on the same blade.

Estimation of ammonium excretion by epifauna. Ammonium excretion rates per square centimeter were determined for Membranipora membranacea and Obelia geniculata colonies independent of seaweed tissue on settlement plates (C. D. Hepburn et al. unpubl. data); these are the dominant epifaunal species on Macrocystis pyrifera at Harington Point and have morphologies typical of seaweed-dwelling bryozoans and hydrozoans. Excretion rates $\left(\mathrm{NH}_{4}{ }^{+} \mu \mathrm{mol}\right.$ $\mathrm{cm}^{-2} \mathrm{~h}^{-1}$ ) from colonies on settlement plates were extrapolated using the surface area of hydroids and 
bryozoans on tagged fronds to give estimates of total ammonium excretion by epifauna in micromoles per hour per frond.

The potential uptake of nitrogen by tagged Macrocystis pyrifera was estimated from uptake rates of ammonium and nitrate by $M$. pyrifera blade tissue colonized by the hydroid Obelia geniculata and adjacent blade tissue from the same blade that was free from colonization (C. D. Hepburn et al. unpubl. data). Uptake rates were determined for $30 \mathrm{~cm}^{2}$ blade discs during the summer low-nitrogen period (January 2000) and the winter high-nitrogen period (June 2000) at $6 \mu \mathrm{M}$ nitrate and $4 \mu \mathrm{M}$ ammonium (C. D. Hepburn et al. unpubl. data). As concentrations used in uptake experiments were often higher than those observed in seawater nutrient samples collected at the study site, uptake rates were modified to those that would be expected at ambient concentrations. This was achieved by assuming a linear relationship between uptake and ambient nitrogen concentration. Ammonium and nitrate uptake by $M$. pyrifera blade tissue does have a positive linear relationship with concentration in the surrounding seawater at lower concentrations (Haines \& Wheeler 1978, Gerard 1982a, Kopzcak 1994). Average nitrate seawater concentrations from the surface and at $4 \mathrm{~m}$ depth at the time of tagging were used to modify nitrate uptake rates. During the first 2 tagging dates nitrate concentrations were not available, so concentrations from the following year were substituted as an estimate of ambient nitrate concentration during May and June 1998. An average ammonium concentration of $1.96 \mu \mathrm{M}$ from over the entire study period was used to modify ammonium uptake, as no clear seasonal changes were observed for seawater ammonium concentration and ammonium concentrations were often highly variable over periods of $<30$ min (Hepburn 2003). Uptake rates from blade discs were extrapolated to estimate total frond nitrogen uptake from blade surface areas that were determined for each tagged frond (Hepburn 2003). As colonization by bryozoans and hydroids affect nutrient uptake rates by $M$. pyrifera blades, separate calculations were made for the 3 colonization groups (blade tissue free from colonization, hydroid colonized, bryozoan colonized) and these values were pooled to give uptake rates for entire fronds. Uptake rates for blade tissue free of epifauna and that colonized by hydroids were taken directly from uptake experiments (C. D. Hepburn et al. unpubl. data). Nitrogen uptake by bryozoan-colonized blade tissue was estimated by dividing uptake rates of blade tissue free from colonization by 2 , as Membranipora membranacea has been shown to have a barrier effect reducing nitrogen uptake by $50 \%$ (Hurd et al. 1994). Uptake rates from winter were used to estimate frond nitrogen uptake during the period of high tissue nitrogen between May and August, while summer uptake rates were used to estimate nitrogen uptake by tagged fronds during the low-nitrogen period between November and March.

Statistical analyses. For each tagging date, the influence of bryozoan and hydroid colonization on frond growth and nitrogen status was explored using scatter graphs and Pearson product moment correlation analyses. Differences in Macrocystis pyrifera frond growth rates between the 12 tagging dates were determined using 1-way parametric and non-parametric ANOVA. Differences in hydroid and bryozoan cover of blades from the top, middle and base of tagged fronds were determined using a 1-way, non-parametric ANOVA. Percentage cover data was pooled from all tagging dates. Tests for normality (KolmogorovSmirnov test with Lilliefor's correction) and equal variance (Levene median test) were carried out on all data to see if the criteria to perform parametric ANOVA were fulfilled. Non-normal data were normalized by log transformation before any differences were determined using parametric ANOVA with Tukey's posttest. Differences between data with heterogeneous variances were determined using 1-way ANOVA on ranks (Kruskal-Wallis test), with Dunn's post-test. All statistical analyses were carried out using the software package Sigma Stat 2.03 (SPSS).

\section{RESULTS}

\section{Environmental parameters}

Average monthly global radiation began to increase after the winter solstice at Harington Point, reaching a maximum during December/January, before declining once more to lower winter levels (Fig. 2a). A strong seasonal pattern of high seawater nitrate concentrations during winter (June to August) and lower concentrations during summer (December to February) was evident at Harington Point (Fig. 2b). Seawater ammonium concentrations were quite variable $(0.01$ to $4.5 \mu \mathrm{M})$, and, unlike nitrate, no clear seasonal patterns were observed (Fig. 2c). There were no clear differences between nitrate and ammonium concentrations of seawater samples taken from the water's surface and those taken at $4 \mathrm{~m}$.

\section{Frond growth}

Relative growth rates of the blades and internodes of tagged Macrocystis pyrifera fronds exhibited marked seasonal trends, with a high growth period from late 
winter until early summer (August to December) and a low growth period during midsummer until the end of winter (January to July; Fig. 3a,b). No significant correlation was found between light and blade growth rate when compared over the entire study period, but when light and growth values during summer (when tissue nitrogen concentrations were low) were excluded from correlation analyses, blade growth rates showed strong positive correlations with light (Blade 1, $\mathrm{r}=0.893, \mathrm{p}=0.004$; Blade 2, $\mathrm{r}=0.907, \mathrm{p}=0.002$; Blade 3, $\mathrm{r}=$ $0.900, p=0.002$ ). Summer growth values (January to March) were removed from analyses because $M$. pyrifera exhibited low internal nitrogen concentrations at this time and its growth was considered nitrogen-limited. Internode growth rates were also positively correlated with light when summer values were excluded (Internode 1, r $=0.717, \mathrm{p}=0.045$; Internode $2, r=0.597, p=0.118$; Internode $3, r=0.858, p=0.006$ ).

Rates of new blade production by the apical meristems of tagged Macrocystis pyrifera individuals followed no clear seasonal patterns (0.34 to 0.74 ) over the study period other than a peak during January 1999, when maximum rates of 1.1 new blades per day were observed (Fig. 3c). The January 1999 peak was not observed at the same time a year later, with levels of new blade production being $50 \%$ lower during January 2000 (1-way ANOVA on ranks, $H_{9}=$ $32.196, \mathrm{p}<0.001)$. New blade production was positively correlated with light over the entire study period $(\mathrm{r}=0.764$, $\mathrm{p}=0.003)$.

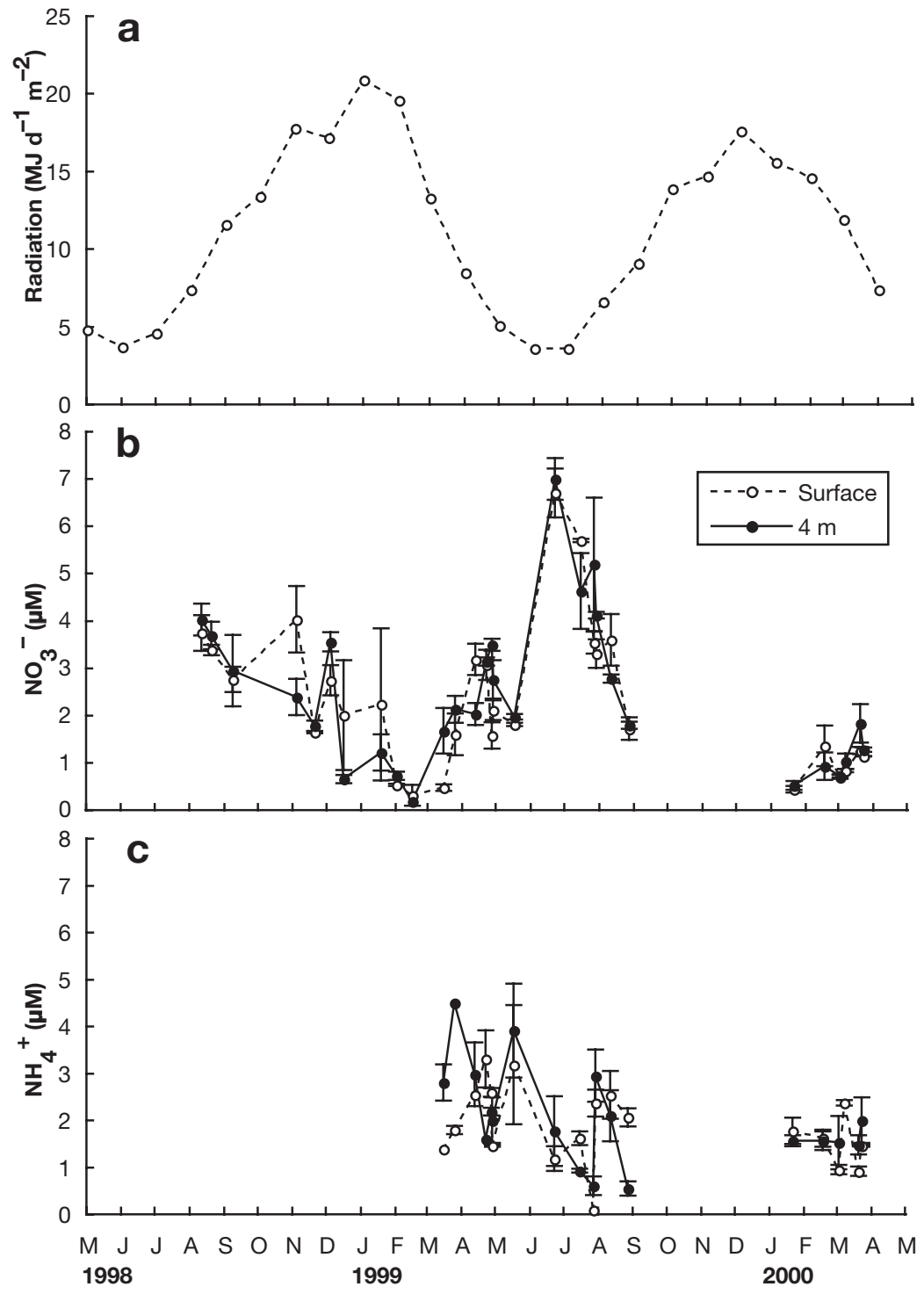

Fig. 2. (a) Monthly averages of daily global radiation from the Musselburgh weather Station, Dunedin. Seawater nitrate (b) and ammonium (c) concentrations from within the Macrocystis pyrifera kelp bed at Harington Point. Points for seawater nitrogen concentrations represent means $\pm 1 \mathrm{SE}(\mathrm{n}=3)$ of samples taken from the surface and near the substratum at $4 \mathrm{~m}$

\section{Frond nitrogen status}

Strong seasonal trends were evident for the soluble tissue nitrate concentrations of blade tissue from the top, middle and base of tagged Macrocystis pyrifera fronds (Fig. 4a), being higher during the winter (May to August) and declining through spring to minimum levels during December 1998 of $1 \mu \mathrm{mol} \mathrm{g}^{-1}$ dry weight. Soluble tissue nitrate of blades from all sections of tagged M. pyrifera fronds was positively correlated to seawater nitrate concentration (top, $\mathrm{r}=0.908, \mathrm{p}=$ 0.000 ; middle, $r=0.798, p=0.003$; base, $r=0.496, p=$
0.121 ) and negatively correlated to light (top, $r=$ $-0.792, \mathrm{p}=0.002$; middle, $\mathrm{r}=-0.750, \mathrm{p}=0.049$; base, $\mathrm{r}=-0.582, \mathrm{p}=0.047$ ).

Soluble tissue ammonium concentrations of Macrocystis pyrifera blade tissue did not follow the same clear seasonal trends observed for soluble tissue nitrate concentration (Fig. 4b). During the winter, ammonium provided between 4 and $12 \%$ of the soluble nitrogen in blade tissue. Due to the decline in internal nitrate concentrations during spring, soluble ammonium became more important over summer, providing between 45 and $84 \%$ of soluble nitrogen. 


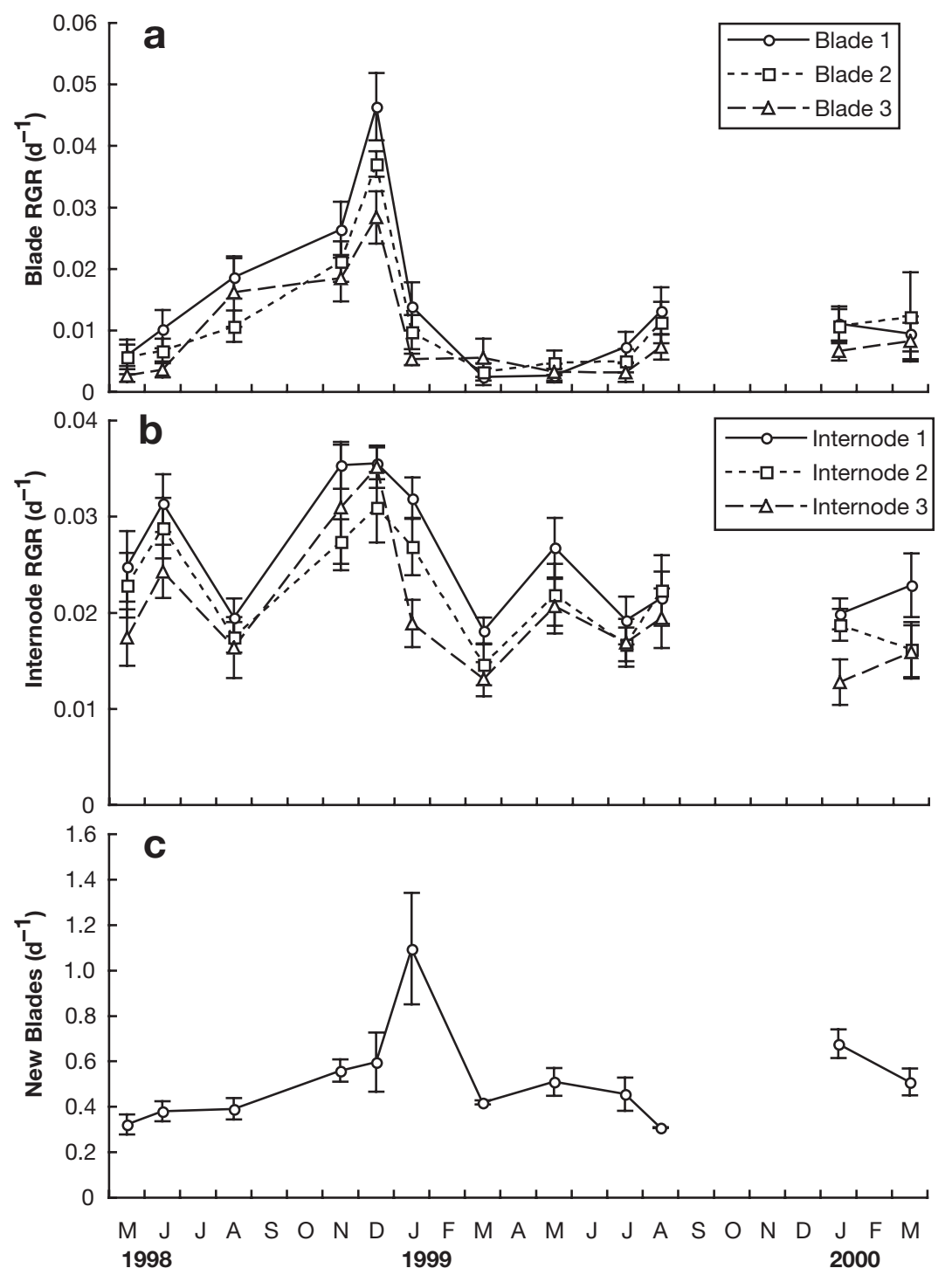

Fig. 3. Macrocystis pyrifera. Relative growth rates (RGR) of (a) blades and (b) internodes, and (c) rates of the production of new blades by the apical meristem at Harington Point between April 1998 and August 1999 and during January and February 2000. Points represent means \pm 1 SE ( $n=7$ to 19) levels of colonization when compared to blades from the middle and top of tagged fronds over all tagging dates. There were also significantly higher levels of bryozoan cover for the blades sampled in the middle of tagged fronds than those for blades at the top (1-way ANOVA on ranks, $H_{2}=$ 184.871, $\mathrm{p}<0.001)$. Hydroids were more common near the top of tagged fronds than bryozoans, and there was no significant difference between hydroid colonization of blades from the middle and base of fronds. Hydroid colonization of blades from the top third of fronds was, however, significantly lower than that from the other 2 groups (1-way ANOVA on ranks, $H_{2}=71.322$, $\left.\mathrm{p}<0.001\right)$. Percentage hydroid colonization of Macrocystis pyrifera blades was not determined for the first 2 tagging events, as they were not conspicuous at the study site until August 1998.

\section{Estimation of ammonium excretion by epifauna}

Highest rates of ammonium excretion by bryozoans on tagged Macrocystis pyrifera fronds were observed during the high nitrogen winter period in 1998, with maximum rates of $7.0 \mu \mathrm{mol}$ fronds $\mathrm{h}^{-1}$ observed during July 1998 (Fig. 6). Hydroids provided most ammonium during the summer of 1998/1999, and during January 1999 excretion reached a maximum of $20.7 \mu \mathrm{mol}$ fronds $\mathrm{h}^{-1}$. Hydroids also excreted substantial amounts of ammonium during July 1999 and August 1998 and 1999.

\section{Colonization by epifauna}

Percentage bryozoan and hydroid cover of Macrocystis pyrifera blade tissue fluctuated greatly between tagging events. Averaged over all tagging events, hydroids (Fig. 5a) covered $7 \%$ (range 0 to $85 \%$ ) of blade surfaces, while bryozoans (Fig. 5b) were found on $2 \%$ (range 0 to $60 \%$ ) of the blade surface area. Bryozoans were more common on $M$. pyrifera during winter, while hydroid colonization events were much more variable and did not follow any obvious temporal patterns.

Bryozoan colonies covered most blade tissue at the base of tagged fronds, having significantly higher
Maximum frond uptake occurred during spring and early summer, with lower rates of uptake during autumn and winter (Fig. 6). During August 1998, when bryozoan ammonium excretion rates were maximal, bryozoans could provide up to $107 \%$ of the nitrogen required for inorganic nitrogen uptake at ambient concentrations by fronds. During the summer, when hydroid ammonium excretion rates were maximal, potential frond uptake rates were also much higher. Despite high summer uptake rates, hydroid ammonium still had the potential to provide an average of $122 \%$ of the nitrogen needed for inorganic nitrogen uptake at ambient seawater nitrogen concentrations during January 1999. 


\section{Impact of epifaunal colonization on frond growth and nitrogen status}

Only during December 1998 and January 1999, when hydroid colonies covered the greatest amount of blade tissue, were there any clear correlations between the growth and nitrogen status of Macrocystis pyrifera and epifaunal colonization levels. Combined correlations of December and January tagging events showed that new blade production by fronds increased with increasing levels of hydroid colonization (Fig. 7a, Table 1). There was also a positive relationship between new blade production and soluble ammonium concentrations from blade tissue taken from the top of tagged fronds (Fig. 7b, Table 1). Soluble tissue ammonium concentrations of blade tissue were also positively correlated with levels of hydroid colonization of tagged M. pyrifera fronds (Fig. $7 \mathrm{c}, \mathrm{d}$, Table 2).

Negative relationships were observed between blade growth of tagged Macrocystis pyrifera fronds and the hydroid colonization levels of blades from the middle and base of fronds during December 1998 and January 1999 (Table 1). A negative relationship was also observed at this time between blade growth and ammonium concentrations of blade tissue, although these relationships were inconsistent between blades and not particularly strong.

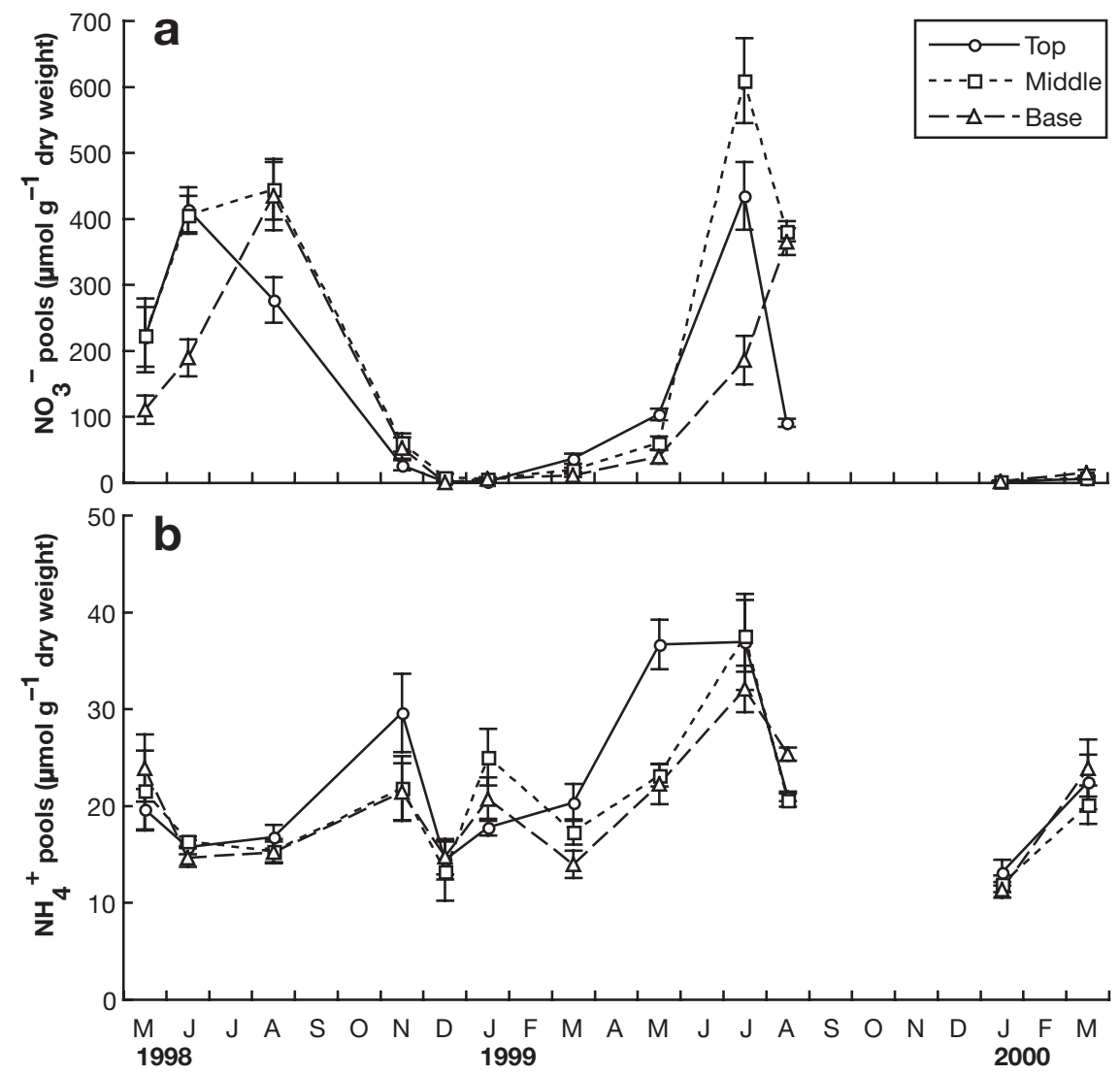

Fig. 4. Macrocystis pyrifera. (a) Soluble tissue nitrate and (b) ammonium concentrations of blade tissue from the top, middle and base of tagged fronds at Harington Point between April 1998 and August 1999 and from January until March 2000. Points represent means \pm 1 SE $(n=7$ to 19$)$

No clear relationship was observed between internode growth and hydroid colonization of $M$. pyrifera blades during the December/January period (Table 1).

At no time during this study was colonization by bryozoans correlated with growth or nitrogen status of tagged Macrocystis pyrifera fronds.

Table 1. Macrocystis pyrifera. Frond growth parameters correlated to levels of hydroid colonization and soluble ammonium pools of blades from the top, middle and base of tagged fronds during December 1998 and January 1999. Correlation coefficients (r) and p-values for 12 (new blades production), 15 to 19 (blade growth) and 19 to 20 (internode growth) observations. RGR = relative growth rates

\begin{tabular}{|c|c|c|c|c|c|c|c|c|c|c|c|c|c|c|c|c|}
\hline & \multicolumn{8}{|c|}{ - \% Hydroid } & \multicolumn{8}{|c|}{$-\mathrm{NH}_{4}{ }^{+}$pools -} \\
\hline & \multicolumn{2}{|c|}{ Тор } & \multicolumn{2}{|c|}{ Middle } & \multicolumn{2}{|c|}{ Base } & \multicolumn{2}{|c|}{ Total } & \multicolumn{2}{|c|}{ Top } & \multicolumn{2}{|c|}{ Middle } & \multicolumn{2}{|c|}{ Base } & \multicolumn{2}{|c|}{ Total } \\
\hline & $\mathrm{r}$ & $\mathrm{p}$ & $\mathrm{r}$ & $\mathrm{p}$ & $\mathrm{r}$ & $\mathrm{p}$ & $\mathrm{r}$ & $\mathrm{p}$ & $\mathrm{r}$ & $\mathrm{p}$ & $\mathrm{r}$ & $\mathrm{p}$ & $\mathrm{r}$ & $\mathrm{p}$ & $\mathrm{r}$ & $\mathrm{p}$ \\
\hline Blade 1 (RGR) & -0.367 & 0.123 & -0.528 & 0.020 & -0.494 & 0.032 & -0.611 & 0.005 & -0.424 & 0.079 & -0.296 & 0.234 & -0.258 & 0.302 & -0.433 & 30.072 \\
\hline Blade 2 (RGR) & -0.481 & 0.043 & -0.769 & $<0.001$ & -0.590 & $<0.001$ & $-0.776<$ & $<0.001$ & -0.386 & 0.126 & -0.605 & 0.010 & -0.096 & 0.713 & -0.518 & 80.033 \\
\hline Blade 3 (RGR) & -0.463 & 0.071 & -0.912 & $<0.001$ & -0.613 & 0.012 & $-0.840<$ & $<0.001$ & -0.484 & 0.067 & -0.383 & 0.158 & -0.367 & 0.179 & -0.548 & 80.035 \\
\hline Internode 1 (RGR) & 0.326 & 0.174 & -0.088 & 0.720 & 0.089 & 0.717 & 0.055 & 0.824 & -0.249 & 0.320 & -0.183 & 0.466 & -0.142 & 0.575 & -0.255 & 50.308 \\
\hline Internode 2 (RGR) & 0.106 & 0.656 & 0.185 & 0.436 & 0.215 & 0.362 & 0.167 & 0.482 & 0.304 & 0.206 & -0.054 & 0.827 & -0.042 & 0.863 & 0.040 & 0.872 \\
\hline Internode 3 (RGR) & -0.348 & 0.144 & -0.553 & 0.014 & -0.542 & 0.017 & -0.619 & 0.005 & -0.243 & 0.331 & -0.320 & 0.196 & -0.302 & 0.224 & -0.429 & 90.076 \\
\hline New blades & 0.314 & 0.320 & 0.715 & 0.009 & 0.764 & 0.003 & $0.849<$ & $<0.001$ & 0.797 & 0.002 & 0.471 & 0.122 & 0.065 & 0.842 & 0.525 & 0.080 \\
\hline
\end{tabular}




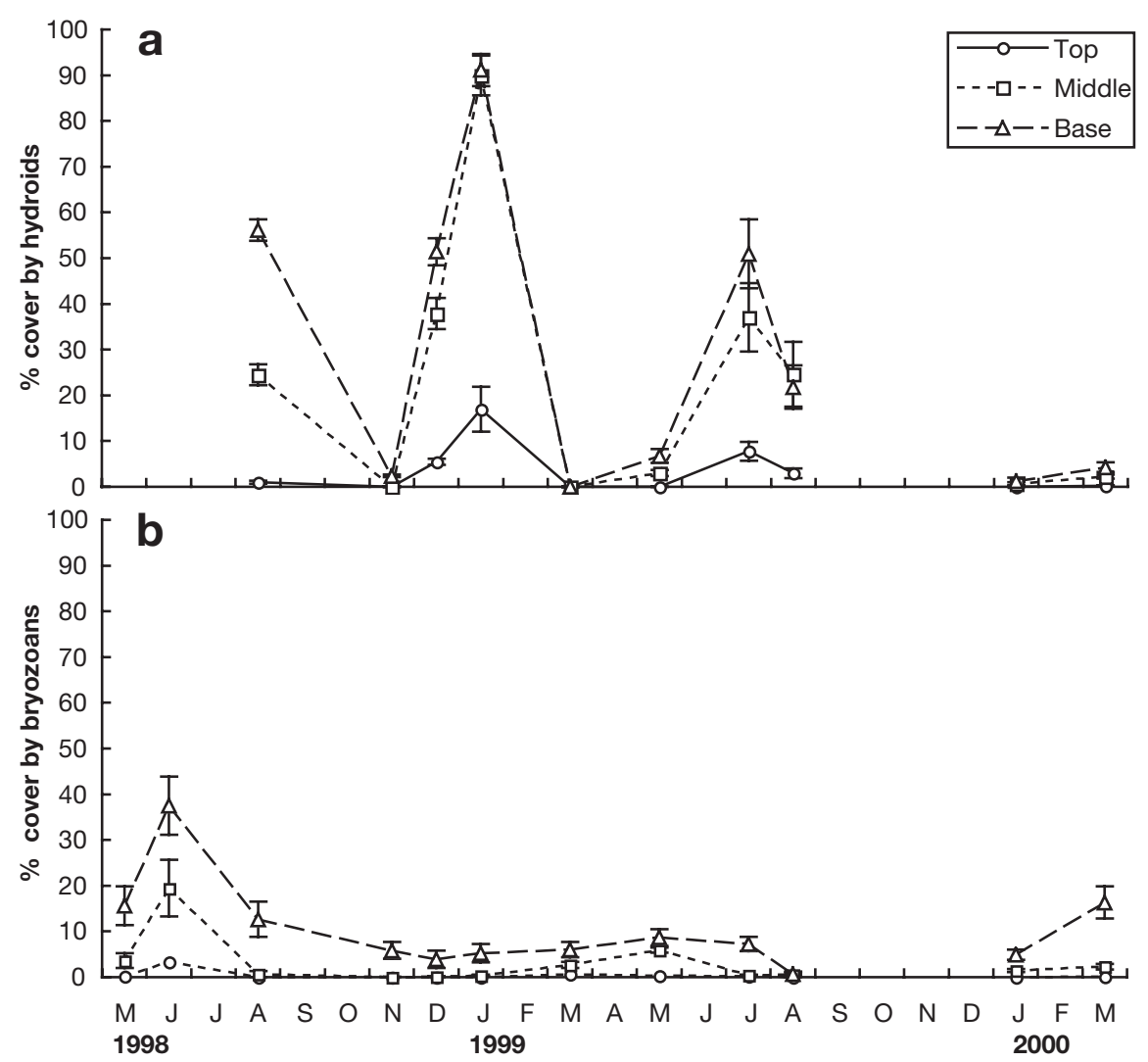

Fig. 5. Macrocystis pyrifera. Percentage cover of blade surfaces by (a) hydroids and (b) bryozoans from the top, middle and base of tagged fronds at Harington Point between April 1998 and August 1999 and from January until March 2000. Points represent means $\pm 1 \mathrm{SE}$ ( $\mathrm{n}=7$ to 19$)$

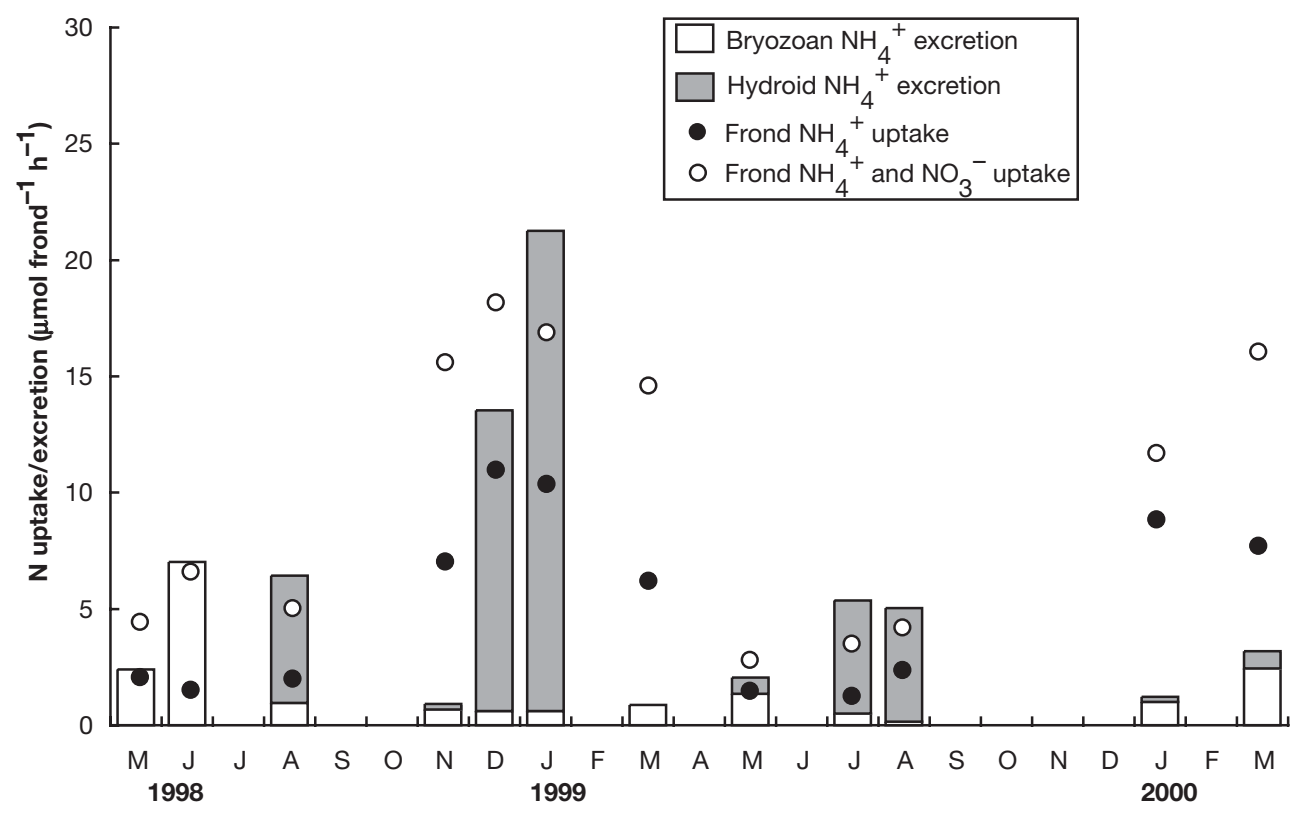

Fig. 6. Macrocystis pyrifera. Potential ammonium excretion by hydroids and bryozoans on tagged fronds, and potential frond uptake rates for ammonium and total inorganic nitrogen (nitrate and ammonium) between April 1998 and August 1999 and from January until March 2000 
Fig. 7. Macrocystis pyrifera. Frond growth parameters and nutrient status of tagged fronds in relation to colonization by hydroids at Harington Point during December and January 1998/ 1999. (a) New blade production by the apical meristem in relation to percent hydroid colonization averaged from blades over the entire frond. (b) New blade production in relation to soluble ammonium concentrations of blade tissue from the top third of tagged fronds. (c) Soluble ammonium of blade tissue from the top of tagged fronds in relation to percent blade hydroid colonization averaged over the entire frond. (d) Average soluble tissue ammonium concentrations pooled from blade tissue from the top, middle and base of tagged fronds in relation to percent blade hydroid colonization averaged over the whole frond
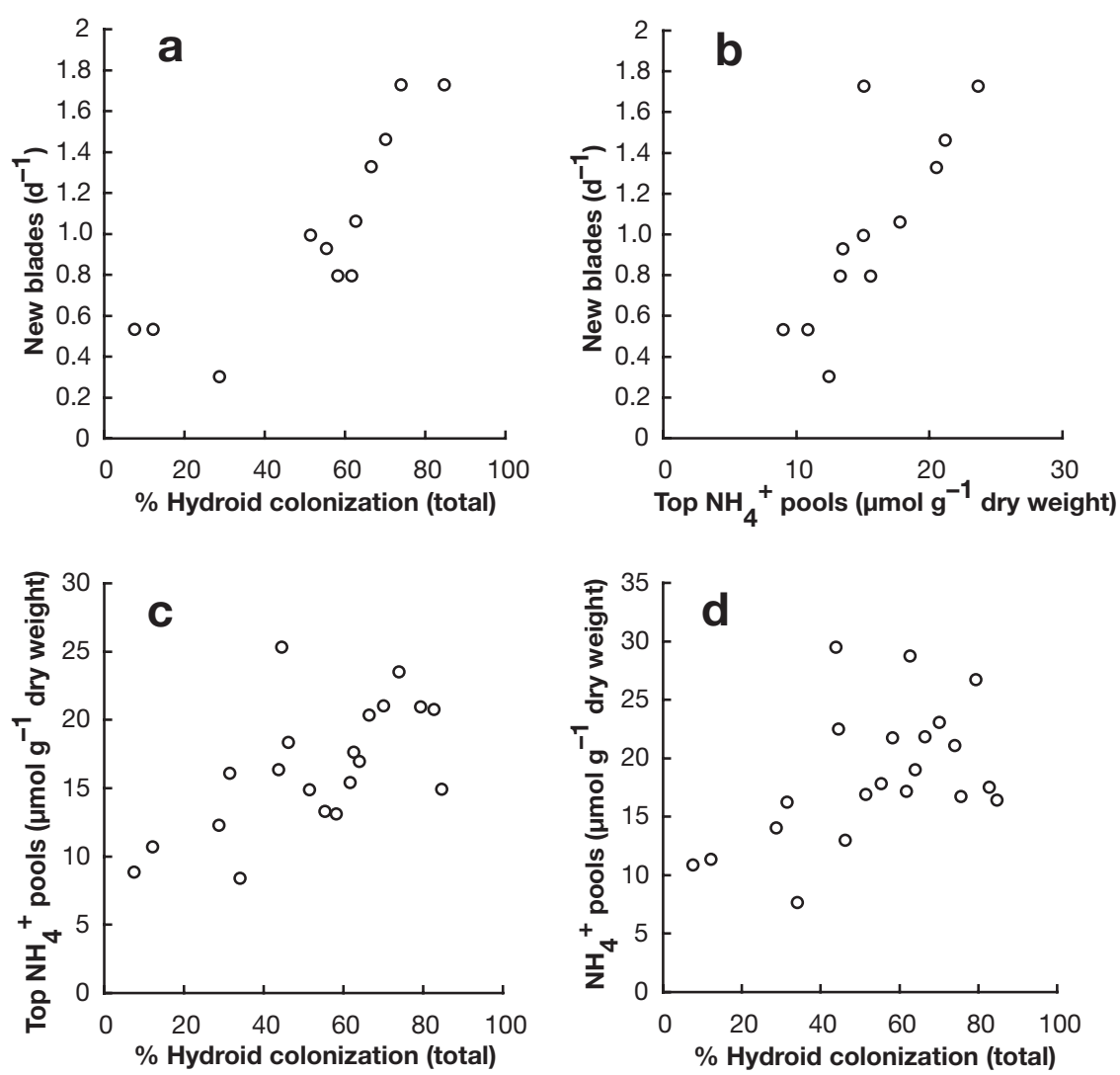

Table 2. Macrocystis pyrifera. Soluble ammonium pools of blade tissue correlated to hydroid colonization levels for blade tissue from the top, middle and base of tagged fronds during December 1998 and January 1999. Correlation coefficients (r) and p-values for 21 observations

\begin{tabular}{|c|c|c|c|c|c|c|c|c|}
\hline & \multicolumn{2}{|c|}{ Top } & \multicolumn{2}{|c|}{ Middle } & \multicolumn{2}{|c|}{ Base } & \multicolumn{2}{|c|}{ Total } \\
\hline & $\mathrm{r}$ & $\mathrm{p}$ & $\mathrm{r}$ & $\mathrm{p}$ & $\mathrm{r}$ & $\mathrm{p}$ & $\mathrm{r}$ & $\mathrm{p}$ \\
\hline $\mathrm{NH}_{4}{ }^{+}$Top & 0.125 & 0.590 & 0.602 & 0.004 & 0.626 & 0.002 & 0.632 & 0.002 \\
\hline $\mathrm{NH}_{4}^{+}$Middle & 0.051 & 0.826 & 0.511 & 0.018 & 0.483 & 0.027 & 0.382 & 0.088 \\
\hline $\mathrm{NH}_{4}{ }^{+}$Base & -0.114 & 0.623 & 0.189 & 0.412 & 0.152 & 0.511 & 0.163 & 0.485 \\
\hline $\mathrm{NH}_{4}{ }^{+}$Total & 0.015 & 0.949 & 0.598 & 0.004 & 0.568 & 0.008 & 0.506 & 0.019 \\
\hline
\end{tabular}

\section{DISCUSSION}

Throughout this study there was no evidence of negative effects of epifaunal colonization on Macrocystis pyrifera frond growth, and, at certain times of year, epifauna may provide advantages to heavily colonized macroalgae via nitrogen provision. Epifauna are rarely observed on actively growing sections of macroalgae and, therefore, are unlikely to have a negative effect on growth of their algal substratum (Norton 1971, Cancino et al. 1987). As a result of strong evolutionary pressure it is likely that epifauna, which have an obligate relationship with their seaweed substratum, evolve in a way that would limit harm to the algae they live
Evidence supporting the prevailing view that colonial animals that live on the surfaces of algae significantly harm their algal substratum has been developed entirely from studies that have investigated the effects of sheet-forming bryozoan colonies on underlying algal tissue. Bryozoan colonies may have marked negative effects on the tissue they colonize, but tissue free from colonization may compensate for any negative impacts of the colonization of other sections of the thallus. The fact that sessile animals are rarely found on actively growing sections means that they may only shade or damage slow-growing tissue that does not provide a significant amount of assimilates to meristematic regions (Cancino et al. 1987). As observed in 
this study the actual amount of algal tissue covered by sessile fauna may be low during most times of the year. Sessile epifauna have the potential to provide benefits to the macroalgae they colonize via nitrogen provision. These benefits are more likely for more diffuse stoloniferous epifauna, like hydroids, that have no negative effects on the seaweed tissue they colonize (C. D. Hepburn et al. unpubl. data) and can be present in significant numbers during periods when macroalgae are nitrogen-limited.

\section{Ammonium provision by epifauna}

For epifauna to provide significant amounts of ammonium to their seaweed substratum it is important that some or all of the following prerequisites are fulfilled: (1) ambient nitrogen should be low, (2) algae should have low internal tissue nitrogen contents, (3) the colonized algae should have a high affinity for ammonium uptake, (4) small-scale hydrodynamic processes should retain ammonium at the seaweed surface and turnover rates of the surrounding seawater should be low (Taylor \& Rees 1998). During the summer of 1998/1999, when hydroid colonization of Macrocystis pyrifera was at a maximum, each of these pre-requisites was fulfilled. Both (1) ambient and (2) internal nitrogen concentrations were at low levels, and M. pyrifera growth was nitrogen-limited. (3) $M$. pyrifera blade tissue colonized by hydroids had a 7 -fold higher affinity for ammonium uptake than that observed for similar blade tissue when $M$. pyrifera was nitrogen replete (C. D. Hepburn et al. unpubl. data). (4) The growth form of both $M$. pyrifera and the hydroid colonies would facilitate retention of hydroid ammonium at the blade's surface for uptake by colonized fronds. The canopy formed by $M$. pyrifera attenuates water flow (Jackson 1998), therefore reducing the mixing of water enriched with ammonium by epifauna with the surrounding water column. On a smaller scale, the hair-like polyps of hydroid colonies that extend from the blade surface may increase the thickness of velocity boundary layers surrounding the algae, thus maintaining ammonium at the blades surface and allowing increased uptake by colonized blades.

To provide advantages to colonized macroalgae via nitrogen provision, sessile epifauna must be present in significant numbers during periods of nitrogen limitation. Bryozoan colonies were not common on the blades of Macrocystis pyrifera during summer and, as a result, were unable to provide nitrogen to $M$. pyrifera when it was nitrogen-limited. In other geographic locations bryozoans can be common on Macrocystis spp. during low nitrogen periods and may be more important in ameliorating nitrogen limitation (Hurd et al. 1994). Hydroid colonization events were temporally variable, and included one particularly large colonization event during December 1998 and January 1999, when hydroid levels reached $85 \%$ cover of blade surfaces and were common along the entire frond. Hydroids may be present in high numbers in low nitrogen periods, but the unpredictable seasonal pattern of hydroid colonization means that the contribution of hydroid-derived nitrogen to the nitrogen budget of $M$. pyrifera is highly variable over different years.

Where epifauna live on the seaweed thallus can also influence the importance of the ammonium they excrete. During this study epifauna were most commonly found at the base of Macrocystis pyrifera fronds, on older blade tissue that grows slowly or not at all (Kain 1982, Brown et al. 1997). However, the stipe of $M$. pyrifera has sieve-tube elements that can transport carbon and nitrogen along the stipe (Parker 1965, 1966, Lobban 1978b, C. D. Hepburn et al. unpubl. data), indicating that $M$. pyrifera may be able to utilize ammonium excreted by epifauna on distant, slowgrowing blades, for growth near frond apices.

During December and January hydroids could provide, on average, between 71 and $122 \%$ of the nitrogen for uptake by tagged Macrocystis pyrifera fronds. Ammonium provision by epifauna over this 2 mo period was likely to have a significant effect on the nitrogen status and growth of $M$. pyrifera during nitrogen-limited growth. Excretion rates by sessile epifauna may be much higher than those estimated in this study, as excretion rates described here were determined in filtered seawater devoid of food items (C. D. Hepburn et al. unpubl. data). Further work investigating excretion of ammonium by hydroids and bryozoans during feeding at a range of food concentrations is warranted.

\section{Growth response by Macrocystis pyrifera to hydroid colonization}

The enhanced production of new blades during December 1998 and January 1999 is most likely explained by the provision of ammonium by hydroids from the highly colonized blade tissue from the middle of tagged Macrocystis pyrifera fronds. Ammonium concentrations from blade tissue from the middle of the tagged fronds showed a positive relationship with hydroid colonization: blade tissue from the middle of fronds had significantly higher percent nitrogen contents than blade tissue from either the top or base (Hepburn 2003). It is likely that nitrogen was exported from the blade tissue with high nitrogen contents, i.e. from the middle of fronds, to the strongest nitrogen sink of the frond, the rapidly growing apical meristem. Tagging fronds during summer 2000 provided further 
evidence that the high epifaunal loads observed on $M$. pyrifera during December 1998 and January 1999 had a positive effect on frond growth. Sampling was resumed during this time in an attempt to observe the same period of enhanced growth that was detected a year earlier. During 2000 very low levels of hydroid colonization were observed, and no clear peak of new blade production was observed.

The negative relationship observed between Macrocystis pyrifera blade and stipe growth and hydroid colonization was a result of a decline in growth related to nitrogen limitation rather than any direct relationship with hydroid colonization. It is unlikely that hydroid colonization negatively affected blade growth as hydroid colonies were rare on the apical blades where blade growth rates were determined. The fact that no enhancement of blade/internode growth was observed during December 1998 and January 1999 is probably a result of the apical meristem providing a stronger sink for hydroid-derived nitrogen than that provided by tagged blades and sections of stipe (internodes) further down the frond (Lobban 1978b).

\section{Seasonal patterns of nitrogen status and growth of Macrocystis pyrifera}

Macrocystis pyrifera blade and internode growth followed a pattern of light-limited growth during winter and nitrogen-limited growth during summer and autumn at Harington Point, which is typical of Macrocystis spp. frond growth in temperate shallow water environments (Lobban 1978a, van Tussenbroek 1989). Maximum growth rates were observed just before soluble nitrogen reserves were exhausted in early summer, when light levels were maximal. Despite the presence of light levels appropriate for rapid growth during the summer, rates of blade and internode growth declined and remained low. This low summer growth was likely due to nitrogen limitation, as evidenced by lower seawater nitrogen concentrations, the exhaustion of internal nitrogen pools and C:N values of $>15$ (Hanisak 1983, Hepburn 2003). Two weeks of seawater nitrate concentrations $<1 \mu \mathrm{M}$ are considered enough to limit the growth of $M$. pyrifera (Gerard 1982b). In the present study concentrations of 1 to $2 \mu \mathrm{M}$ nitrate and a similar amount of ammonium were observed in seawater samples during early summer, but growth still declined. The high growth rates of $M$. pyrifera during spring and early summer may have been reliant on high internal concentrations of nitrogen, which were exhausted during December. Flux of seawater nitrogen into the kelp bed and uptake of nitrogen by $M$. pyrifera may not have been enough to maintain high frond growth rates. Nitrogen limitation of $M$. pyrifera growth during the summer appears typical for Otago Harbor, having been previously observed for kelp beds at Aquarium Point (Brown et al. 1997).

The availability of ammonium in the water column and high affinity for ammonium uptake by nitrogen-limited Macrocystis pyrifera tissue (Haines \& Wheeler 1978, Kopczak 1994) may have allowed increased use of ammonium as a nitrogen source during the summer. This idea is supported by the greater contribution of the ammonium to the soluble nitrogen pool of $M$. pyrifera blade tissue and the observation of ammonium uptake rates of blade tissue 7 -fold higher during summer compared to winter at Harington Point (C. D. Hepburn et al. unpubl. data).

Although no significant correlation between light and blade and internode growth was observed over all tagging events, when the low growth rates observed during summer were excluded from analyses very strong positive correlations were observed between growth of both parameters and light. This supports the conclusion that dual limitation of Macrocystis pyrifera growth by both light and nitrogen occurs, with light being limiting during winter and spring, while nitrogen becomes limiting during summer and autumn.

Acknowledgements. We thank S. Bell who provided excellent technical support that aided in the development and execution of this study, and M. Tilson, R. Graham and S. Miller for help with fieldwork. We are grateful to C. Hart, students from Marine Botany Research Group and staff from the Department of Botany of the University of Otago for their support. Thanks to D. Gordon (NIWA) for advice identifying bryozoans, and to K. Mcgill (NIWA) for access to light data. We thank 3 anonymous reviewers for critical comments that improved this manuscript. This study was supported by a Division of Science Award to C.D.H., a University of Otago Research Grant and a University of Otago Bridging Grant to C.L.H.

\section{LITERATURE CITED}

Barrales HL, Lobban CS (1975) The comparative ecology of Macrocystis pyrifera, with emphasis on the forests of Chubut, Argentina. J Ecol 63:657-677

Bernstein BB, Jung N (1979) Selective pressures and coevolution in a kelp canopy community in Southern California. Ecol Monogr 49:335-355

Brown MT, Nyman MA, Keogh JA, Chin NKM (1997) Seasonal growth of the giant kelp Macrocystis pyrifera in New Zealand. Mar Biol 129:417-424

Cancino JM, Muñoz J, Muñoz M, Orellana MC (1987) Effects of the bryozoan Membranipora tuberculata (Bosc.) on the photosynthesis and growth of Gelidium rex. J Exp Mar Biol Ecol 113:105-112

Dayton PK (1985) Ecology of kelp communities. Annu Rev Ecol Syst 16:215-245

Dean TA, Jacobsen FR (1984) Growth of juvenile Macrocystis pyrifera (Laminariales) in relation to environmental factors. Mar Biol 83:301-311

De Burgh ME, Fankboner PV (1978) A nutritional association between the bull kelp Nereocystis luetkeana and its epi- 
zoic bryozoan Membranipora membranacea. Oikos 31: $69-72$

Dieckmann GS (1980) Aspects of the ecology of Laminaria pallida (Grev.) J. Ag. off the Cape Peninsula (South Africa). I. Seasonal growth. Bot Mar 23:579-585

Dixon J, Schroeter SC, Kastendiek J (1981) Effects of the encrusting bryozoan, Membranipora membranacea, on the loss of blades and fronds by the giant kelp Macrocystis pyrifera (Laminariales). J Phycol 17:341-345

Duggins DO, Eckman JE, Sewell AT (1990) Ecology of understory environments. II. Effects of kelps on recruitment of benthic invertebrates. J Exp Mar Biol Ecol 143:27-45

Eckman JE, Duggins DO (1991) Life and death beneath macrophyte canopies: effects of understory kelps on growth rates and survival of marine, benthic suspension feeders. Oecologia 87:473-487

Foster MS, Schiel DR (1985) The ecology of giant kelp forests in California: a community profile. Biol Rep 85 (7.2)

Fraschetti S, Giangrande A, Terlizzi A, Migilieta MP, DellaTommasa L, Boero F (2002) Spatio-temporal variation of hydroids and polychaetes associated with Cystoseira amentacea (Fucales: Phaeophyceae). Mar Biol 140:949-957

Gerard VA (1982a) In situ rates of nitrate uptake by giant kelp Macrocystis pyrifera: tissue differences, environmental effects, and predictions of nitrogen limited growth. J Exp Mar Biol Ecol 62:211-224

Gerard VA (1982b) Growth and utilization of internal nitrogen reserves by the giant kelp Macrocystis pyrifera in a low-nitrogen environment. Mar Biol 66:27-35

Gerard VA, Mann KH (1979) Growth and production of Laminaria longicruris (Phaeophyta) populations exposed to different intensities of water movement. J Phycol 15:33-41

Hagermann L (1966) The macro- and microfauna associated with Fucus serratus (L.), with some ecological remarks. Ophelia 3:1-43

Haines KC, Wheeler PA (1978) Ammonium and nitrate uptake by Hypnea musciformis (Rhodophyta) and Macrocystis pyrifera (Phaeophyta). J Phycol 14:319-324

Hanisak MD (1983) The nitrogen relationships of marine macroalgae. In: Carpenter EJ, Capone DG (eds) Nitrogen in the marine environment. Academic Press, New York, p 699-730

Hepburn CD (2003) The influence of sessile epifauna on the ecology and physiology of the giant kelp Macrocystis pyrifera (L.) C. Agardh. PhD thesis. University of Otago, Dunedin, New Zealand

Hurd CL, Durante KM, Chia FS, Harrison PJ (1994) Effect of bryozoan colonization on inorganic nitrogen acquisition by the kelps Agarum fimbriatum and Macrocystis integrifolia. Mar Biol 121:167-173

Hurd CL, Harrison PJ, Druehl LD (1996) Effect of seawater velocity on inorganic nitrogen uptake by morphologically distinct forms of Macrocystis integrifolia from wavesheltered and exposed sites. Mar Biol 126:205-214

Hurd CL, Durante KM, Harrison PJ (2000) Influence of bryozoan colonization on the physiology of the kelp Macrocystis integrifolia (Laminariales, Phaeophyta) from nitrogen-rich and -poor sites in Barkley Sound, British Columbia, Canada. Phycologia 39:435-440

Jackson GA (1998) Currents in the high drag environment of a coastal kelp stand off California. Cont Shelf Res 17: 1913-1928

Kain JM (1975) The biology of Laminaria hyperborea. 7. Reproduction of the sporophyte. J Mar Biol Assoc UK 55: 567-582

Kain JM (1982) Morphology and growth of Macrocystis pyrifera in New Zealand and California. Mar Biol 67:143-157
Kopczak CD (1994) Variability of nitrate uptake capacity in Macrocystis pyrifera (Laminariales, Phaeophyta) with nitrate and light availability. J Phycol 30:573-580

Lambert WJ, Levin PS, Berman J (1992) Changes in the structure of a New England (USA) kelp bed: the effects of an introduced species. Mar Ecol Prog Ser 88:303-307

Lobban CS (1978a) Growth of Macrocystis integrifolia in Barkley Sound, Vancouver Island, B.C. Can J Bot 56: 2707-2711

Lobban CS (1978b) Translocation of ${ }^{14} \mathrm{C}$ in Macrocystis pyrifera (giant kelp). Plant Physiol (Rockville) 61:585-589

Manriquez PH, Cancino JM (1996) Bryozoan-macroalgal interactions: do epibionts benefit? Mar Ecol Prog Ser 138: 189-197

Mercado JM, Carmona R, Niell FX (1998) Bryozoans increase available $\mathrm{CO}_{2}$ for photosynthesis in Gelidium sesquipedale (Rhodophyceae). J Phycol 34:925-927

Muñoz J, Cancino JM, Molina MX (1991) Effect of encrusting bryozoans on the physiology of their algal substratum. J Mar Biol Assoc UK 71:877-882

Norton TA (1971) An ecological study of the fauna inhabiting the sublittorial marine algae Saccorhiza polyschides (Lightf), Batt. Hydrobiologia 37:215-231

Orlov DV (1996) The role of larval settling behaviour in determination of the specific habitat of the hydrozoan Dunamena pumila (L.). Larval settlement in Dunamena pumila (L.). J Exp Mar Biol Ecol 208:73-85

Oswald RC, Seed R (1986) Organisation and seasonal progression within the epifaunal communities of coastal macroalgae. Cah Biol Mar 27:29-40

Oswald RC, Telford N, Seed R, Happey-Wood CM (1984) The effect of encrusting bryozoans on the photosynthetic activity of Fucus serratus L. Estuar Coast Shelf Sci 19:697-702

Parke M (1948) Studies on the British Laminariaceae. I. Growth in Laminaria saccharina (L.) Lamour. J Mar Biol Assoc UK 27:651-709

Parker BC (1965) Translocation in the giant kelp Macrocystis. I. Rates, direction, quality of $\mathrm{C}^{14}$-labelled products and fluorescein. J Phycol 1:41-46

Parker BC (1966) Translocation in Macrocystis. III. Compositon of sieve tube exudate and identification of the major $\mathrm{C}^{14}$-labelled products. J Phycol 2:38-41

Probyn TA, Chapman AR (1983) Summer growth of Chordaria flagelliformis (O.F. Muell.) C. Ag.: physiological strategies in a nutrient stressed environment. J Exp Mar Biol Ecol 73:243-271

Ryland JS (1974) Observations on some epibionts of gulf-weed, Sargassum natans (L.) Meyen. J Exp Mar Biol Ecol 14:17-25

Scheibling RE, Hennigar AW, Balch T (1999) Destructive grazing, epiphytism, and disease: the dynamics of sea urchin-kelp interactions in Nova Scotia. Can J Fish Aquat Sci 56:2300-2314

Seed R, O'Connor RJ (1981) Community organization in marine algal epifaunas. Annu Rev Ecol Syst 12:49-74

Steneck RS, Graham MH, Bourque BJ, Corbett D, Erlandson JM, Estes JA, Tegner MJ (2002) Kelp forest ecosystems: biodiversity, stability, resilience and future. Environ Conserv 29:436-459

Taylor RB, Rees TAV (1998) Excretory products of mobile epifauna as a nitrogen source for seaweeds. Limnol Oceanogr 43:600-606

van Tussenbroek BI (1989) Seasonal growth and composition of fronds of Macrocystis pyrifera in the Falkland Islands. Mar Biol 100:419-430

Yoshioka PL (1982) Role of planktonic and benthic factors in the population dynamics of the bryozoan Membranipora membranacea. Ecology 63:457-468 